\title{
Comparative assessment of biological activity of peloids of Ukraine of different genesis
}

\section{BABOV Konstantin ${ }^{1}$, GUSHCHA Sergey ${ }^{1}$, KOIEVA Khrystyna ${ }^{1}$, STRUS Oksana ${ }^{2}$, NASIBULIN Boris ${ }^{1}$, DMITRIEVA Galina ${ }^{1}$, ARABADJI Mikhailo ${ }^{1}$, PLAKIDA Alexander ${ }^{1}$}

\author{
Corresponding author: PLAKIDA Alexander: E-mail: aplakida@mail.ru
}

${ }^{1}$ State Institution «Ukrainian Research Institute of Medical Rehabilitation and Balneology of the Ministry of Health of Ukraine», Odessa, Ukraine

2 Danylo Halytsky Lviv National Medical University, Lviv, Ukraine

\begin{abstract}
The article presents the results of comprehensive studies of the influence of peloids from different geographic regions of Ukraine and different genesis on the course of experimental pathology.

Methods:At the first stage of research we have determined the type of peloids these are medium-mineralized weakly sulfide magnesium-sodium silt peloids, low-ash organic sapropels, and peat low-mineralized high-ash sulfide-free peloids. Physicochemical parameters have been established: mass fraction of moisture, volumetric weight, hydrogen sulfide content, contamination with particles with a diameter greater than $0.25 \times 10-3 \mathrm{~m}$, shear stress, stickiness, specific heat capacity, the content of organic substances, colloidal complex, the concentration of water conduit ions $(\mathrm{pH})$, redox potential (Eh). In the second stage of the study, 55 white rats were examined for the state of the liver's detoxification function (by carrying out a metabolic test using sodium thiopental) and the morphological form of the liver in normal conditions and toxic alcoholic hepatosis. The toxic alcoholic hepatosis model was induced by daily ( 30 days) intragastric watering of animals with a $25 \%$ solution of ethyl alcohol. From the 15 th day, the rats received a course of applications: a cake with the corresponding peloids was applied to the bare part of the back.

Results: It was determined that the peloids used had a positive effect on animals' condition, which was expressed in the restoration of the detoxification function of the liver and its structural and functional organization. The most substantial positive effect is observed when using silt-sulfide peloids, which, according to the authors, is due to the peculiarities of their physicochemical composition (increased content of magnesium, chlorides, sodium, as well as hydrogen sulfide).

Conclusion: Based on the results obtained, it was concluded that the studied peloids meet the criteria for the quality of therapeutic peloids in terms of physicochemical parameters, biological activity, and expands the possibilities of their application in balneology.
\end{abstract}

Keywords: liver, toxic alcoholic hepatosis, rats, peloids,

\section{Introduction}

According to the legislation of Ukraine, "Medicinal mud (peloids) are considered to be peat, sapropelic, silt, sulfide, freshwater clay silts, mud, hydrothermal silts, composed of mineral and organic substances, which have undergone complex transformations due to physicochemical, chemical, biochemical processes and represent is a homogeneous plastic mass, which is used in a heated state for mud therapy."

Healing muds are divided into:

- silt mud of salt water bodies (sulfide)

- silt mud of fresh water bodies (sapropels)

- peat;

- pseudo-volcanic: hydrothermal, mud, and hot springs mud.

Also, it is possible to subdivide mud into mainly inorganic (sulfide, hill) and organic (peat and sapropel) (1).

It should be noted that today there are differences in the classification of peloids in different countries (2). Therefore, in our country, work is being carried out to implement Ukraine's integration into the European Union (EU) to organize scientific and technical cooperation to harmonize domestic regulatory documents with European ones $(3,4)$.

In Ukraine, curative mud (peloids) is represented by almost all known types. For example, sapropels are natural organo-mineral formations, deposits of freshwater reservoirs, formed from dead plant and animal organisms, minerals of biochemical and chemical origin, and mineral components.

Sapropel (from the Greek saprós - rotten and pelós - silt, mud) - rotting sludge. It is a gelatinous homogeneous mass of greenish-brown color, rich in organic matter. The organic matter of sapropels contains liquid and solid hydrocarbons, esters, organic acids, alcohols, resins, readily hydrolysable, and humic compounds with high biological activity $(5,6)$.

The most suitable for treatment by their properties are sapropels of organic and organo-silicate origin. In Ukraine, sapropel peloids are distributed mainly in Polesie - p. Vilchan, (Zhytomyr region), Mikulinetskoye field (Ternopil region). But, the most famous in Ukraine are the sapropel deposits of the Shatsk lakes (7). An example of the use of sapropels in Eastern Europe is the famous Romanian resort Eforie Nord located between Lake Techirghiol and the Black Sea coast, near Constanta. In countries such as Latvia and Belarus, much attention is paid to research and the use of sapropels in the economy and health improvement and treatment (8).

Peat peloids are organogenic bog deposits formed as a result of partial bacterial decomposition of peat-producing 
plants under conditions of excess moisture and poor oxygen access. They contain more than $50 \%$ organic matter, and the degree of their bacterial processing (degree of decomposition) is about $40 \%$. Deposits of peat medicinal peloids are formed mainly in the forest-steppe medico-geographical zone of Ukraine's northern and western regions. Gypsum and vitriol peat with a mineralized (more than $2 \mathrm{~g} / \mathrm{l}$ ) mud solution are considered valuable. Among the most famous deposits: Shklovsky, Velikolyubinskoe, Morshinskoe (Lviv region), Nemirovskaya, Voytovetskoe (Vinnytsia region), Nastasivske (Ternopil region), Cherchensky, Pidpecherinske, Osmolodsky (Ivano-Frankivsk region), and Zhuravitsky deposit in Volyn region (9)

In Europe, Hungary is an example of the use of peloids in balneotherapy, including peat ones.

In Hungary, six types of medical peloids are used: peloids from Makó, Kolop, Héviz, Hajdúszoboszló, Alsópáhok (Georgikon), and peloid from Austria, Neydharting, which is a peat. These peloids can be classified into three groups based on their origin:

- the Makó, Kolop, and Hajdúszoboszló peloids are inorganic because of their notable mineral content and tiny organic component;

- the Héviz peloid represents the mixed peloids, which are rich in volcanic minerals and contain 20-25\% Sphagnum peat;

- the Georgikon' peat belongs to the organic peloids containing a many organic components and humins (10).

In Ukraine, mainly used for medicinal purposes are silt deposits of salt water bodies (silt sulfide mud), which are concentrated in the country's southern region. These are the Black Sea estuaries and estuaries of the Azov Sea (11). Sulfide-silt mud is a soft, velvety, plastic mass of black color with the smell of hydrogen sulfide and ammonia, consisting of: - a skeleton (or a crystalline skeleton); - colloidal fractions; - mud solution. The crystalline skeleton makes up $20-50 \%$ of its mass - the coarse-dispersed part of the peloids consists of: - silicate particles; - gypsum; - phosphates, calcium carbonates, magnesium, and other salts; - organic residues.

To a large extent, these peloids's biological activity determined by the concentration of macro- and microelements and biologically active substances (12). Peloids of this type are used in the balneotherapy of diseases of the musculoskeletal system for therapeutic purposes in many conditions (13).

One of the necessary conditions for using of peloids in balneotherapy and cosmetology practice is a comprehensive assessment of their composition and bioactivity. For this, a complex of geologicalgeographical, physicochemical, microbiological studies using laboratory animals is used. Determination of the safety (toxicity) of peloids and subsequent preclinical studies are being carried out, which are the scientific basis for further clinical trials $(1,14)$.

Purpose of the work: to determine the characteristics of the biological effect of peloids of various origins on rats with alcoholic hepatosis.

\section{Materials and research methods.}

The study used three types of the most common peloids in Ukraine.

1. silt sulfide peloids of the Kuyalnitsky estuary (Kuyalnik resort near Odessa), Southwestern coast of the Black Sea.

2. Sapropel peloids of the Prybych deposit (Lake Prybych), part of the Shatsk lakes group of the Volyn region.

3. Peat peloids of the "Semirenki" deposit, located near the village of "Semirenki" in the Mirgorodsky district of the Poltava region.

In determining the physicochemical characteristics of the studied peloids used methods regulated by the Passport of the Standardization Center, which was accredited by the National Accreditation Agency of Ukraine (15) and metrological characteristics of analytical methods, which are given in the form of 5 Passports of the Ukrainian state center of standardization and quality control of natural and preformed means and in the corresponding regulatory documentation $(16,17)$.

The studies were carried out on sexually mature white female Wistar rats weighing $180.0-200.0$ g. Work with animals was carried out in an experimental biological clinic (vivarium) State Institution "Ukrainian Research Institute of Medical Rehabilitation Therapy of Ministry of Health of Ukraine ", m. Odesa. The studies followed with legal documents -" Protocol No. 52 dated 08.22.2019 from the Commission on Bioethics "(18). All rats were divided into five groups. Group 1 consisted of intact animals, which served as control (15 animals). Group 2 consisted of 10 animals with a model of toxic alcoholic hepatosis (TAH) without a treatment course.

Groups 3, 4, and 5 consisted of rats (10 animals in each group) with a TAH model that received a course of procedures with silt-sulfide peloids (group 3 of rats), sapropels (group 4 of animals), and peat peloids respectively, group 5 of animals. The TAH model was reproduced by daily administaring of a $25 \%$ ethanol solution into the esophagus in rats at a dose of $1.5 \%$ of the bodyweight (at the rate of $4 \mathrm{~g}$ of $96 \%$ ethanol per $1 \mathrm{~kg}$ of body weight) for 30 days.

To correct TAH, we carried out a course of applications from the fifteenth to the thirtieth day of the experiment. Lozenges applied the rats by with the corresponding peloids, $2 \times 2 \mathrm{~cm}^{2}$ in size, on a shaved area of the back (closer to the tail). The temperature of the cake was maintained at a constant level $\left(39-40^{\circ} \mathrm{C}\right)$. The course consisted of 6 procedures for 20 minutes, which were carried out every other day. On the 30th day of the experiment, the liver's functional state was assessed 
according to the Speransky method, using hexenal or sodium thiopental (19).

This technique makes it possible to estimate the metabolic rate of thiopental, which is carried out by the cytochromeP-450-dependent monooxygenase system of hepatocytes and characterizes one of the leading liver's function, detoxification, by the duration of sleep of animals caused by the action of anesthesia. The animals were injected with sodium thiopental at a dose of $80 \mathrm{mg} / \mathrm{kg}$. For the study, 55 animals were selected, in which the duration of drug-induced sleep was, on average, 60 minutes, and the time to fall asleep was, on average, 3 minutes. These data served as control indicators. The time the animals fell asleep characterized the central nervous system's state of functional activity (CNS). If the time to fall asleep increases compared to the control, this indicates the of the test substance's stimulating effect. A decrease in the time to fall asleep implies suppressing the central nervous system's cortical cells' activity.

At the end of the course, the animals were taken out of the experiment by decapitation under ether anesthesia. At autopsy, two liver pieces with a volume of $1 \mathrm{~cm}^{3}$ were removed from the rats. The first piece was fixed for 24 hours in a $4 \%$ paraformaldehyde solution, passed through alcohols of increasing concentration, and poured into celloidin. From the obtained blocks, histological sections of 7-9 $\mu \mathrm{m}$ thick were made, stained with hematoxylineosin, according to the Van Giesonon technique. The obtained preparations were used for microscopic studies of structural changes in the liver. The second piece was frozen with dry carbon dioxide $\left(-70^{\circ} \mathrm{C}\right)$, histochemical reactions were performed on the prepared cryostat sections to determine the activity of succinate dehydrogenase (LDH) and lactate dehydrogenase (LDH) according to Lojda Z.'s recipe (20). The enzyme activity was evaluated in conventional units of optical density (c.u.). The methods used are given in the guidelines and approved by the Ministry of Health of Ukraine $(19,21)$. Statistical processing of the data obtained in a series of experiments was carried out using biomedical research Statistica and Exel programs, mean values and standard errors were calculated $(M \pm \mathrm{m})$. According to the Student's tables significant shifts were considered those within the confidence limits, less than $<0.05$.

\section{Results and its discussion.}

According to the modern classification, the Kuyalnik estuary peloids belong to medium and highly mineralized weakly sulfide sodium chloride or magnesium sodium silt peloids. With a total mineralization of $137.1 \mathrm{~g} / \mathrm{l}$, the concentration of hydrogen sulfide in them is $0.021 \mathrm{~g} / \mathrm{l}$, magnesium $6.8 \mathrm{~g} / 1$, chlorides $80.4 \mathrm{~g} / \mathrm{l}$, sodium $31.3 \mathrm{~g} / 1$ (11). Mud deposits of the Kuyalnitsky estuary are black plastic marks of mules with the smell of hydrogen sulfide $(0.15-0.23 \%)$, low contamination by particles with a diameter of more than $0.25 \cdot 10-3 \mathrm{~m}(0.05-1.62 \%)$, slightly acidic reaction of the medium $6.55-6.95$ units $\mathrm{pH}$, the value of the oxidation-reduction potential (Eh) $230--350 \mathrm{mV}$, which indicates the predominance of reduction processes.

The value of the mass fraction of moisture is 47.50 $61.50 \%$, bulk density $1.39-1.55$; bias voltage 367.9 551.8 Pa, stickiness 763.7 - $1180.3 \mathrm{~Pa}$, specific heat 2, 50 - $2.78 \mathrm{~kJ} / \mathrm{kg} \cdot \mathrm{K}$. Organic carbon content (for air-dry substance) $1.84-2.14 \%$, corresponds to the values typical for silt sulfide peloids.

2. Sapropelic peloids of the lake. Prybych are algal mules, uniform in composition, dark green in color, and are classified as low ash organic sapropels. The sediments of the lake are characterized by a neutral reaction of the environment -7.0 units. $\mathrm{pH}$, oxidation-reduction potential (Eh) - $-80 \mathrm{mV}$, hydrogen sulfide content $-0.006 \%$. The value of the mass fraction of moisture is $96.15 \%$, the volumetric weight is 1.02 ; stickiness - $606.33 \mathrm{~Pa}$, bias voltage - $294.30 \mathrm{~Pa}$, ash content - $10.84 \%$; specific heat $4.06 \mathrm{~kJ} / \mathrm{kg} \cdot \mathrm{K}$. Contamination with mineral particles with a diameter of more than $0.25 \cdot 10-3 \mathrm{~m}-0.035 \%$. Organic carbon content (on the air-dry matter) - 29.69\%.

3. Peloids of the "Semyrenki" deposit are peat bogs, lowmineralized, high-ash, sulfide-free or weakly sulfide peat mud. They are represented by dark brown peat, homogeneous with a very weak odor of hydrogen sulfide $0.0012-0.0020 \%$, which have a weakly acidic reaction $5.50-5.75 \mathrm{pH}$., The value of the redox potential is +210 $+280 \mathrm{mV}$. The mass fraction of moisture in peloids is $68.12-75.41 \%$. Clogging with mineral particles with a diameter of more than $0.25 \times 10-3 \mathrm{~m}$ is $0.17-1.25 \%$, bulk density $1.05-1.12$, stickiness value $694.30-833.12 \mathrm{~Pa}$, bias voltage $466.00-637,70 \mathrm{~Pa}$. Organic carbon content (on the air-dry matter) $12.40-19.33 \%$.

According to physiological studies (table 1), the development of TAH is accompanied by changes in drug sleep; it increased by 29.68 minutes. $(44 \%)(p<0.01)$, which indicates a decrease in detoxification function in animals of group 2. At the same time, the time of falling asleep of the animals of the 2nd group significantly and significantly decreased - by $0.77 \min (28 \%)(p<0.01)$, which indicates the suppression of the functional state of the central nervous system. In rats of group 3, the use of silt-sulfide peloids has a significant corrective affect - the duration of falling asleep and the duration of drug sleep are fully restored.

In rats of groups 4 and 5, a lesser curative effect was revealed. Applications with sapropels in rats of group 4 lead to an increase in the time of falling asleep by 0.32 min and a decrease in the duration of drug sleep by 11.75 min as compared with group 2 of rats with TAH. The tendency to restore of thiopental test parameters was established in rats of group 5 under the influence of applications with peat poloids. Their indices are insignificantly converted compared to the index of the rats 
of the group with uncorrected TAH. They significantly differ from the index of the 1st group of healthy animals $(\mathrm{p}<0.05)$.

Table 1. Functional state of the central nervous system and the state of detoxification activity of the liver in rats with TAG according to thiopental test data $(\mathrm{M} \pm \mathrm{m})$

\begin{tabular}{|l|c|c|c|c|l|}
\hline Indicators & $\mathbf{1}$ group & $\mathbf{2}$ group & $\mathbf{3}$ group & 4 group & 5 group \\
\hline Falling asleep time, & $\mathbf{2 , 7 2} \pm$ & $\mathbf{1 , 9 5} \pm$ & $\mathbf{3 , 1 5} \pm$ & $\mathbf{2 , 2 7} \pm$ & $\mathbf{2 , 0 1}$ \\
min & $\mathbf{0 , 1 7}$ & $\mathbf{0 , 1 9 *}$ & $\mathbf{0 , 2 8}$ & $\mathbf{0 , 1 1 *}$ & $\mathbf{0 , 2 5 *}$ \\
\hline Sleep duration, min & $\mathbf{6 1 , 3 6} \pm$ & $\mathbf{8 8 , 2 3} \pm$ & $\mathbf{6 6 , 4 8} \pm$ & $\mathbf{7 6 , 4 8} \pm$ & $\mathbf{8 0 , 2 1} \pm$ \\
& $\mathbf{1 , 4 5}$ & $\mathbf{2 , 1 5 *}$ & $\mathbf{2 , 1 7}$ & $\mathbf{2 , 4 1 *}$ & $\mathbf{2 , 8 7 ^ { * }}$ \\
\hline
\end{tabular}

Note. * - significant changes $(\mathrm{p}<0.05)$ were calculated in comparison between the control group and the group with pathology

Macroscopic examination of the liver of rats of group 2 showed that its surface is smooth, the front edge is sharp, the liver tissue is yellow-brown. The microscopic examination of the lobular structure of the liver is not broken. In the lobule, the arrangement of hepatocytes is disordered. In hepatocytes, the cytoplasm is lumpy, the nuclei of medium size are juicy colored. A significant number of hepatocytes contain fatty inclusions. Between the cells, and in some of them, there are inclusions of eosinophilic hyaline masses.

The vessels are full-blooded. SDH activity in hepatocytes $(6.00 \pm 0.37)$ c.u., LDH activity $(6.00 \pm 0.20)$ c.u., at a norm of LDH activity in hepatocytes $(4.00 \pm 0.21)$ c.u. This indicates an increase in the use of alternative substrates for energy production. In general, it can be argued that in rats of group 2, on the 30th day of TAH development, manifestations of fatty degeneration of the liver and imbalance in the activity of redox enzymes are determined.

In rats of group 3, after the course with silt-sulfide peloids, the restoration of the liver's brown color was macroscopically determined. Microscopically, it was established that the liver parenchyma's lobular organization is preserved, the vessels are congestive fullblooded. The hepatocytes in the lobules are disordered; their cytoplasm is basophilic, homogeneous, the nuclei are small, dark, vacuoles in the cytoplasm are not detected, as well as hyaline inclusions. SDH activity in hepatocytes of the lobule center $(5.0 \pm 0.11)$ c.u., at the periphery $(6.0 \pm$ $0.23)$ c.u.; LDH activity $(7.0 \pm 0.30)$ c.u. That is, specific changes indicate a weakening of the activity of redox enzymes in comparison with the data of group 2.

Morphological studies of the liver after the completing the courses of applications with sapropelic and peat peloids determined the similarity of these changes and some differences from the picture observed when using siltsulfide peloids. Macroscopically, in rats of groups 4 and 5, the liver had a smooth surface, a sharp front edge, and the liver tissue's yellowish tint. The lobularity of the liver parenchyma organization was clearly defined.

The triad vessels and the central vein are full-blooded, with signs of stasis in some of them. The hepatocytes' arrangement is disordered; their cytoplasm is homogeneous, the nuclei of most hepatocytes are small, dark. In group 4 rats, some of the hepatocytes have small vacuoles, and in group 5 rats, some of the hepatocytes contain small drops of eosinophilic substance. The SDH activity is the same throughout the lobule and in hepatocytes is $(5.0 \pm 0.12)$ c.u. The LDH activity is also the same and is $(5.0 \pm 0.19)$ c.u. That is, the morphology of the liver parenchyma is better restored in group 3 .

Conclusion. The study results showed that the differences in the rehabilitation effect of peloids in animals with the TAH model are associated with the peculiarities of their natural genesis and physicochemical composition. The most significant impact of silt-sulfide peloids is high mineralization, meaningful hydrogen sulfide content, and magnesium ions, which have potent biological activity and affect various links in metabolism. Also, the TAH model used in rats induces significant pathological changes in the rat organism. It can be assumed that with less severe pathological processes that do not cause overstrain of the body's adaptive systems, the use of sapropel and peat peloids will be more effective.

\section{Conclusions}

1. The physicochemical composition of the peloids of the Kuyalnitsky estuary of the Odessa region, the Pribich lake of the Volyn region, and the Semyrenki deposit of the Poltava region of Ukraine has been determined. According to the research results, the Kuyalnitsky estuary peloids were classified as medium- and highlymineralized weakly sulfide sodium chloride or magnesium-sodium silt peloids. The peloids of Lake Pribich are classified as low-ash organic sapropels; the Semyrenki deposit peloids are low-mineralized, high-ash, sulfide-free or weakly-sulfide peat peloids. Physicochemical indicators: mass fraction of moisture, volumetric weight, hydrogen sulfide content, contamination with particles with a diameter greater than $0.25 \times 10^{-3} \mathrm{~m}$, shear stress, stickiness, specific heat, organic matter content, colloid complex, the concentration of water conduit ions $(\mathrm{pH})$, the redox potential (Eh) of all three peloids does not go beyond the peloid quality criteria.

2. The use of silt-sulfide peloids leads to the restoration of the liver's structural and functional organization and the activity of the cytochrome-P-450-dependent monooxygenase system of hepatocytes. At the same time, signs of a violation of the central nervous system's functional state disappear. Sapropel and peat peloids have a unidirectional, but less pronounced a curative effect on the central nervous system's state and the structural and the liver's functional condition. Microscopically, a decrease in the manifestations of fatty degeneration, was determined in hepatocytes. The detoxification function of the liver is partially restored - the duration of drug sleep is significantly reduced. 
3. The data obtained allow us to believe that - the studied peloids meet the criteria for the quality of medicinal peloids in terms of physicochemical indicators, biological activity, which expands the possibilities of their application in practical medicine.

\section{References:}

1. Pro zatverdzhennya Poryadku zdiysnennya medyko-biolohichnoyi otsinky yakosti ta tsinnosti pryrodnykh likuval'nykh resursiv, vyznachennya metodiv yikh vykorystannya: nakaz vid 02.06.2003 r. № 243 MOZ Ukrayiny About the statement of the Order of realization of a medico-biological assessment of quality and value of natural medical resources, definition of methods of their use: the order from 02.06.2003 № 243 of the Ministry of Health of Ukraine https://zakon.rada.gov.ua/laws/show/z0752-03\#Text. Ukrainian).

2. Gomes C, Carretero MI, Pozo M, Maraver F, Cantista P. et al. Peloids and pelotherapy: Historical evolution, classification and glossary. Applied Clay Science. 2013;75-76:28-38. DOI: 10.1016/j.clay.2013.02.008.

3. Credo of the European Spas Association. Spas and Health Resorts in Europe, Brussels, 20th May 2004. http://www.espaehv.com/en/reppres_2008en.pdf.

4. Nikipelova OM, Nikolenko SI, Solodova LB. On the project of safety performance of therapeutic muds (peloids). A project of the safety performance of therapeutic muds (peloids), harmonized reguirements of thewith the European Union and the European Association of resorts spa. Odes'kyi Politechnichnyi Universytet. Pratsi. 2013;2(41):205-208. http://pratsi.opu.ua/app/webroot/articles/1382355584.pdf. Ukrainian).

5. Kala KJ, Prashob PKJ, Chandramohanakumar N. Humic substances as a potent biomaterials for therapeutic and drug delivery system. Int App Pharm. 2019;11(3):1-4. DOI https://doi.org/10.22159/ijap.2019v11i3.31421.

6. Strus O, Polovko N. The influence of «Saprogel» in the wound healing process on rats with a full-thickness wound model. Ceska a Slovenska Farmacie: Casopis Ceske Farmaceuticke Spolecnosti a Slovenske Farmaceuticke Spolecnosti. 2020 ;69(2):75-82. https://europepmc.org/article/med/32545986.

7. Pasichnyk MP. Sapropel healing mudof volyn region (Ukraine) Wschodnioeuropejskie Czasopismo Naukowe (East European Scientific Journal). 2020;1(53):26-30. https://eesajournal.com/2020/02/17/sapropelevye-lechebnye-gryazi-volynskojoblasti-ukrainy-26-30/. (in Russian).

8. Stankevica K, Maris K, Līga R, Aija C. Lake Sapropel: a Valuable Resource and Indicator of Lake Development. Advances in Environment, Computational Chemistry and Bioscience. Article December

2012. https://www.researchgate.net/publication/237845326_Lake_Saprop el_a_Valuable_Resource_and_Indicator_of_Lake_Development.

9. Chyr NV, Grab OM. Pryrodoresursnyi potentsial likuvalnykh hriazei dlia potreb sanatorno-kurortnoho hospodarstva Ukrainy [Natural resource potential of curative mud for needs of the resort industry sector of Ukraine]. Proceedings of the international scientific-practical conference "Modern peculiarities of the innovation resource creation and management for the regional tourism and recreation development with youth resource involvement" (Tern., 15-17 october 2015), pp. 206-208. http://elartu.tntu.edu.ua/handle/123456789/7077. (in Ukrainian).

10. Király M, Kővári E, Hodosi K, Bálint PV, Bender T. The effects of Tiszasüly and Kolop mud pack therapy on knee osteoarthritis: a double-blind, randomised, non-inferiority controlled study. Int J Biometeorol. 2020; 64(6):943-950. doi:10.1007/s00484-01901764-4.
11. Kuyal'nyts'kyy lyman: realiyi ta perspektyvy rekreatsiynoho vykorystannya: monohrafiya / Burkyns'kyy B.V. Babov K.D., Nikipelova O.M. ta in.; In-t probl. rynku ta ekon.-ekol. doslidzh. NAN Ukrayiny, DU «UkrNDI med. reabilitatsiyi ta kurortolohiyi MOZ Ukrayiny». Odesa, 2019. 314 s. Kuyalnytskyi estuary: realities and prospects of recreational use: monograph / Burkinsky BV Babov KD, Nikipelova OM etc.; Inst. market and econ.-ecol. research. NAS of Ukraine, SI "UkrNDI med. rehabilitation and balneology of the Ministry of Health of Ukraine ". Odessa, 2019. 314 p. (in Ukrainian).

12. Morer, C., Roques, C., Françon, A. et al. The role of mineral elements and other chemical compounds used in balneology: data from double-blind randomized clinical trials. Int J Biometeorol. 2017;61:2159-2173. https://doi.org/10.1007/s00484-017-1421-2 .

13. Fraioli A, Mennuni G, Fontana M, et al. Efficacy of Spa Therapy, Mud-Pack Therapy, Balneotherapy, and Mud-Bath Therapy in the Management of Knee Osteoarthritis. A Systematic Review. Biomed Res Int. 2018;2018:1042576. doi:10.1155/2018/1042576.

14. Bülent E, Yavuz U, Bahadir K. Comparison of Therapeutic Efficacy of Spa Mud and Bath Applications in the Treatment of Experimentally Induced Psoriasis and Eczema in Rats. Balneo Research Journal. 2020;11(3):252-260. DOI: 10.12680/balneo.2020.349.

15. Atestat akredytatsiyi Natsional'noho ahent·stva $\mathrm{z}$ akredytatsiyi Ukrayiny na vidpovidnist' do vymoh Derzhstandart Ukrayiny ISO/IEC 17025:2017. № 20386 vid 09.06.2020 r. Accreditation certificate of the National Accreditation Agency of Ukraine in accordance with the requirements of Gosstandart of Ukraine ISO IEC 17025: 2017. № $20386 \quad$ dated 09.06.2020http://kurort.gov.ua/images/doc/At_NAAU.jpg. (in Ukrainian).

16. Nikipelova OM. Solodova LB. A guide to the methods of controlling peloids and their preparations. Part 1.Physico-chemical research / Ministry of Health of Ukraine, Ukr. Research Institute of Medical Rehabilitation Therapy. Odesa. 2008: 100 s. (in Ukrainian).

17. Derzhstandart Ukrayiny 7942:2015 Yakist' gruntu. Vyznachennya zol'nosti torfu i torfovoho gruntu. State Standard of Ukraine 7942: 2015 Soil quality. Determination of ash content of peat and peat soil.http://shop.uas.org.ua/ua/katalog-normativnih-dokumentiv/13zakhyst-dovkillya-ta-zdorovya-bezpeka/jakist-gruntuviznachennja-zol-nosti-torfu-i-torfovogo-gruntu.html. Ukrainian)

18. Council Directive 86/609/EEC of 24 November 1986 on the Approximation of the Laws, Regulations and Administrative Provisions on the Member States Regarding the Protection of Vertebrate Animals Used for Experimental and Other Scientific Purposes. Official Journal of the European Communities. 1986;358:1-29.

19. Aleksyeyenko NA, Pavlova OS, Nasibullin BA, Ruchkina AS. Manual methods of research and preformed natural treatment means: natural mineral therapeutic table water and therapeutic water, drinks based on them; artificially mineralized water; peloids, brines, clay, waxes and preparations based thereon. Part 3. Experimental and clinical researches]. Odesa, 2002, 120 p. (in Ukrainian).

20. Lojda Z, Grossrau R, Schiebler TN. Enzyme Histochemistry. A Laboratory Manual. Springer-Verlag Berlin-Heidelberg New York 1979.

21. On approval of the recommendations of the research methods of biological effects of natural medical resources and preformed medicines: of Ministry of Health of Ukraine № 692, from 28.09.09. Kiev:

2009.

http://old.moz.gov.ua/ua/portal/dn_20090928_692.html.

(in 